\title{
Stable carbon isotopes as potential sea-level indicators in salt marshes, North Carolina, USA
}

Andrew C. Kemp ${ }^{1 \star}$, Christopher H. Vane ${ }^{2}$, Benjamin P. Horton ${ }^{1}$ and Stephen J. Culver ${ }^{3}$

1. Sea Level Research Laboratory, Department of Earth and Environmental Science, University of Pennsylvania, Philadelphia, PA 19104, USA

2. British Geological Survey, Kingsley Dunham Centre, Keyworth, Nottingham NG12 5GG, UK

3. Department of Geological Sciences, East Carolina University, Greenville, NC 27858, USA

* Corresponding Author; email kempac@sas.upenn.edu, phone 215573 8502, fax 2158980964 


\section{Abstract}

We compared the use of $\delta^{13} \mathrm{C}$ values and $\mathrm{C}: \mathrm{N}$ ratios from salt-marsh sediments to reconstruct relative sea level (RSL) with an established approach using foraminifera. Analysis of bulkorganic sediment and plant samples collected along transects at two sites in North Carolina, USA demonstrates that sediment $\delta^{13} \mathrm{C}$ values can be used to distinguish between Spartina alterniflora-dominated low marsh $\left(\mathrm{C}_{4}\right.$ photosynthetic pathway, $\delta^{13} \mathrm{C}$ values from $-17.6 \%$ o to 16.1 $\%)$ and Juncus roemerianus-dominated high marsh $\left(\mathrm{C}_{3}\right.$ photosynthetic pathway, $\delta^{13} \mathrm{C}$ values from $-28.2 \%$ to $-21.8 \%$ ) environments. Juncus roemerianus plants undergo little decompositional change in $\delta^{13} \mathrm{C}$ (average $0.8 \%$ ), although there is a clear difference between Spartina alterniflora tissue and bulk-organic sediments (approximately $4 \%$ ). C:N ratios on bulk-organic sediment from freshwater upland and salt-marsh environments converge during early diagenesis, rendering them of little use in reconstructing RSL. The utility of $\delta^{13} \mathrm{C}$ values as a sea-level indicator is limited by the elevational range of $\mathrm{C}_{4}$ plants, making it difficult to recognize salt-marsh sub-environments and improve the precision of RSL reconstructions. Furthermore, Juncus roemerianus-dominated high marsh and freshwater upland sediments cannot be adequately distinguished with $\delta^{13} \mathrm{C}$ values.

Keywords: salt marsh, carbon isotope ratios, sea level, foraminifera, North Carolina 


\section{Introduction}

On low energy, temperate coasts, salt marshes exhibit a strong environmental gradient extending through marine, brackish and freshwater conditions that is driven by the frequency and duration of tidal inundation (e.g. Chapman, 1940, 1960). Vascular plants and microfaunas respond to this gradient by forming distinctive floral and faunal zones that reflect sub-environments along the gradient. This characteristic pattern of zonation can be used to estimate former relative sea level (RSL) by establishing the environmental origin of organic sediment preserved in estuaries, salt marshes and coastal lowlands (e.g. Shennan, 1992). RSL is reconstructed using sea-level indicators, which are physical, biological or chemical features possessing a systematic and quantifiable relationship to elevation in the tidal frame (Shennan, 1986, van de Plassche, 1986). The indicative meaning (Figure 1d) is the elevational range occupied by a sea-level indicator (indicative range) in relation to a contemporaneous tide level (reference water level).

Assemblages of salt-marsh foraminifera are widely used sea-level indicators that can accurately define zones within tidal environments with a precision of up to $\pm 0.05 \mathrm{~m}$ in high marsh settings (Scott and Medioli, 1978; Gehrels, 1994, 2000; Horton and Edwards, 2006). Foraminifera are frequently well preserved in salt-marsh deposits and their low diversity, high abundance assemblages (Sen Gupta, 1999; Gehrels, 2007) lend themselves to quantitative analysis. There are, however, potential difficulties with the application of salt-marsh foraminifera to reconstruct RSL. Interpretation of foraminiferal assemblages in subsurface sediments requires an understanding of the distribution and ecological preferences of modern foraminifera, including infaunal habitation (e.g. Goldstein and Harben, 1993; Ozarko et al., 1997; Saffert and Thomas, 1998), seasonal population fluctuations (e.g. Murray and Alve, 2000) and micro-scale variability (patchiness) in the distribution of foraminifera (e.g. Hippensteel et al., 2000). Post-depositional 
modification of assemblages may also compromise paleoenvironmental reconstructions through selective removal of tests (e.g. Jonasson and Patterson, 1992; Goldstein and Watkins, 1999).

Potential alternative means to reconstruct RSL from salt-marsh sediments include the stable carbon isotopic composition $\left({ }^{13} \mathrm{C}:{ }^{12} \mathrm{C}\right.$ ratio, expressed as $\delta^{13} \mathrm{C}$ in parts per mil (\%o) compared to a standard reference sample, PDB) and the ratio of organic carbon to total nitrogen $(C: N)$ in bulk-organic sediments (e.g. Wilson et al., 2005; Lamb et al., 2006, 2007). Salt-marsh plants using the $\mathrm{C}_{4}$ photosynthetic pathway, create plant tissues with an average $\delta^{13} \mathrm{C}$ composition of $12 \%$ (Schlesinger, 1997) and a range from $-17 \%$ to $-9 \%$ (Chmura and Aharon, 1995). In contrast, plants utilizing the $C_{3}$ photosynthetic pathway have a $\delta^{13} \mathrm{C}$ signature of $-34 \%$ to $-23 \%$ (Chmura and Aharon, 1995). The distinction between these pathways offers a potential means to reconstruct RSL by identifying salt-marsh environments in organic sedimentary sequences (Chmura et al., 1987). Reconstructions with increased precision are possible if salt-marsh zones (low and high marshes characterized by different proportions of $\mathrm{C}_{3}$ and $\mathrm{C}_{4}$ plants) can be recognized (Edwards, 2007). Such an approach requires locations where $C_{3}$ and $C_{4}$ plants have existed together with differing distributions for the period under consideration (Wilson et al., 2005) and $\delta^{13} \mathrm{C}$ is incorporated into organic sediments with little diagenetic change (e.g. Ember et al., 1987; Fogel et al., 1989, Goni and Thomas, 2000). Measured values of $\delta^{13} \mathrm{C}$ and C:N record the balance between autochthonous and allochthonous inputs. The dominant autochthonous component in salt marshes is from vascular plants (Lamb et al., 2006), whilst allochthonous sediment may be derived from fresh, brackish or marine environments as particulate or dissolved material. The contribution of allochthonous inputs (volume and provenance, relative to autochthonous materials) to measured sediment $\delta^{13} \mathrm{C}$ and $\mathrm{C}: \mathrm{N}$ values may be significant in salt-marsh environments (e.g. Lamb et al., 2006; Gebrehiwet et al., 2008). 
We investigated the use of $\delta^{13} \mathrm{C}$ and $\mathrm{C}: \mathrm{N}$ ratios to identify salt-marsh floral zones in bulk-organic sediments and reconstruct RSL in North Carolina, USA. Previous studies using $\delta^{13} \mathrm{C}$ and $\mathrm{C}: \mathrm{N}$ in salt-marsh deposits have used the technique to characterize paleoenvironments and infer vegetation change (e.g. Malamud-Roam and Ingram, 2004; Wilson et al., 2005) or to provide qualitative information about the depositional environment of radiocarbon-dated samples (e.g. Chmura and Aharon, 1995; Törnqvist et al., 2006, 2008). To date, this technique has not been used to quantitatively reconstruct RSL. The $\delta^{13} \mathrm{C}$ and C:N values of surface sediments were measured along environmental and elevational gradients at two microtidal sites to consider the potential accuracy and precision of this approach. We compare $\delta^{13} \mathrm{C}$ and $\mathrm{C}: \mathrm{N}$ values from plants and surface sediments to better understand the effects of early diagenesis on salt-marsh sediments. To demonstrate the application of $\delta^{13} \mathrm{C}$ in reconstructing RSL, we estimated the indicative meaning of 11 Holocene sea-level data points from North Carolina and compared the results to those from a foraminifera-based transfer function approach.

\section{Study Area}

The Atlantic coast of North Carolina is characterised by sounds separating the mainland from the Outer Banks barrier islands (Pilkey et al., 2002). Water in the sounds reflects the balance between freshwater input from rivers and exchange of marine water with the Atlantic Ocean through inlets. The region is micro-tidal and wind-driven water levels regularly exceed the magnitude of astronomical tides. Salt marshes occupy the margins of the sounds where brackish conditions exist (Pilkey et al., 2002). Spartina alterniflora forms narrow bands of low marsh (Adams, 1963; Brinson, 1991; Woerner and Hackney, 1997). Juncus roemerianus covers up to $77 \%$ of salt-marsh area (Eleuterius, 1976) and dominates high marshes (Brinson, 1991). Other common species include Distichlis spicata and Spartina patens, which usually occur as patches in high marsh environments surrounded by Juncus roemerianus. At sites with low 
salinity, Spartina cynusoroides occupies high marshes (e.g. Culver and Horton, 2005). The vertical zonation of salt-marsh plants is limited by the microtidal nature of the study area, but it is this microtidal regime together with continuous sequences of high marsh peat that provides an ideal setting for reconstructing changes in sea level. The study region is representative of a substantial proportion of back-barrier salt marshes on the Atlantic Coast of the USA.

We selected two sites on salt marshes at Oregon Inlet and Sand Point (Figure 1a) that represent different environmental conditions from a larger set of sites where Kemp et al. (2009) documented modern foraminiferal distributions. The Oregon Inlet site is a high salinity (26 psu; Williams et al., 1973; Culver and Horton, 2005), back-barrier marsh located adjacent to the open inlet (Figure 1b). A $250 \mathrm{~m}$ long transect of 15 sampling stations (Figures $1 \mathrm{~b}$ and 2) extended from a narrow (10 $\mathrm{m}$ wide) Spartina alterniflora-dominated low marsh to a large (240 $\mathrm{m}$ wide) high marsh, characterized by Juncus roemerianus, in association with Iva fructescens toward the upper edge of the marsh. The second site, Sand Point, is distal to an open inlet (Figure 1c), resulting in low salinity (8 psu; Schwartz and Chestnut, 1973). The marsh is up to $1500 \mathrm{~m}$ wide and displays a narrow ( $5 \mathrm{~m}$ ), low marsh of Spartina alterniflora that is replaced inland by Juncus roemerianus and followed by a transition to freshwater upland vegetation. The transect included 21 sampling stations extending across the marsh into the surrounding upland (Figures 1c and 2). Similar to many salt-marsh shorelines in the Albemarle-Pamlico estuarine system, this site is experiencing significant erosion and the low marsh receives substantial inputs of reworked highmarsh sediment, which is likely several thousands of years old (Riggs, 2001). Therefore, low marsh environments were not sampled at this site. Tidal flat environments and pioneer stage salt marshes are unusual in North Carolina and were not present at either site.

Salt-marsh plants were collected from three additional sites (Figure 1a). Swan Quarter National Wildlife Refuge (NWR) is situated at the confluence of the Pamlico River with Pamlico Sound; it 
is a large, low salinity salt marsh. Ocracoke is a narrow $(150 \mathrm{~m})$, higher salinity salt marsh on the Outer Banks. Cedar Island is one of the largest salt marshes in North Carolina (up to $6.7 \mathrm{~km}$ wide; Brinson, 1991) and is characterized by salinities between 15 and 20 psu.

\section{Methods}

We analyzed samples from transects at the Oregon Inlet and Sand Point sites to document the modern distribution of foraminifera and geochemical characteristics of salt-marsh sediment. The transects extended perpendicular to the shoreline from low marsh to freshwater upland environments. Positioning of samples reflected changes in elevation and vegetation. Sample elevations were measured by leveling to geodetic benchmarks (Figure 1b, c). The boundaries between floral zones were surveyed at as many as 40 locations at each site to estimate the elevational range of common plants. We measured the boundaries between a) freshwater upland and Juncus roemerianus, b) Spartina alterniflora and Juncus roemerianus and c) the lower limit of Spartina alterniflora. The program VDatum (Hess et al., 2005) enabled conversion from orthometric to tidal elevations (expressed relative to local Mean Tide Level, MTL).

\subsection{Sediment Grain Size and $\delta^{13} C, C: N$ ratios and Total Organic Carbon of Modern Sediments} and Plants

Surface sediment samples $(0-1 \mathrm{~cm})$ were collected for analysis along both transects. Additionally, at Sand Point, we collected 19 samples of Juncus roemerianus and two of Distichlis spicata. Plant material was also collected at Swan Quarter NWR (Spartina alterniflora, Spartina cynusoroides and Spartina patens), Ocracoke (Distichlis spicata, Salicornia sp., Spartina alterniflora, and Spartina patens) and Cedar Island (Iva fructescens, Juncus roemerianus, Spartina alterniflora, Spartina cynusoroides and Spartina patens). Sample grain 
size was measured using laser diffraction after Allen and Thornley (2004) and Hawkes et al. (2007).

For measurement of $\delta^{13} \mathrm{C}$ and $\mathrm{C}: \mathrm{N}$, sediment samples were treated with $5 \% \mathrm{HCL}$ for 18 hours, washed with deionised water, dried in an oven at $40^{\circ} \mathrm{C}$ overnight and milled to a fine powder using a pestle and mortar. Plant samples were washed with deionised water to remove sediment particles, dried in an oven at $40^{\circ} \mathrm{C}$ overnight and milled to a fine powder.

${ }^{13} \mathrm{C} /{ }^{12} \mathrm{C}$ analyses were performed on plant and sediment samples by combustion in a Costech Elemental Analyser coupled on-line to an Optima dual-inlet mass spectrometer. $\delta^{13} \mathrm{C}$ values were calculated to the VPDB scale using a within-run laboratory standard (cellulose, Sigma Chemical prod. no. C-6413) calibrated against NBS-19 and NBS-22. C:N ratios were analysed on the same instrument and the ratios were calibrated through an acetanilide standard. All C:N values are expressed on a weight ratio basis. Replicate analysis indicated a precision of $<0.1 \%$ (1 SD) for $\delta^{13} \mathrm{C}$ and $\mathrm{C}: \mathrm{N}$ measurements.

\subsection{Modern Foraminifera}

We collected surface sediment samples $(0-1 \mathrm{~cm})$ for foraminiferal analysis. Samples were stored in buffered ethanol and stained with rose Bengal (Walton, 1952) to allow identification of live individuals. Samples were sieved to isolate the foraminifera-bearing fraction between $63 \mu \mathrm{m}$ and $500 \mu \mathrm{m}$. Each sample was divided into eight aliquots and a minimum of 200 individuals was counted from a known fraction of the sediment (Scott and Hermelin, 1993; de Rijk, 1995). Salt-marsh foraminifera typically form low diversity assemblages and counts of 200 are representative of the target population (Fatela and Taborda, 2002). Assemblage zones were identified by unconstrained, hierarchical cluster analysis (Kemp et al., 2009). 


\section{Results}

\subsection{Elevational Distribution of Vascular Plants}

Leveling of floral boundaries provided estimates of the local vertical range of Spartina alterniflora and Juncus roemerianus. Despite differences in salinity and tidal range, the elevational distribution of plants at Oregon Inlet and Sand Point is similar. At Oregon Inlet, Spartina alterniflora occupies mean elevations between $-0.09 \mathrm{~m}$ and $0.22 \mathrm{~m}$ MTL; Juncus roemerianus is found from $0.14 \mathrm{~m}$ to $0.42 \mathrm{~m}$ MTL. At Sand Point, Spartina alterniflora was dominant at elevations between $-0.10 \mathrm{~m}$ and $0.11 \mathrm{~m} \mathrm{MTL}$. Juncus roemerianus was the dominant plant at elevations ranging from $0.10 \mathrm{~m}$ to $0.35 \mathrm{~m} \mathrm{MTL}$, but was absent from sites above approximately $0.35 \mathrm{~m} \mathrm{MTL}$, where it was replaced by freshwater upland vegetation.

\section{$4.2 \delta^{13} \mathrm{C}$ and C:N ratios of Modern Salt-Marsh Sediments}

At Oregon Inlet, surface sediments in the Spartina alterniflora low marsh between $0 \mathrm{~m}$ and $28 \mathrm{~m}$ along the transect exhibited $\delta^{13} \mathrm{C}$ values from $-17.6 \%$ to $-16.2 \%$ (average $-17.0 \%$ ) and C:N ratios between 14.8 and 16.1 (Figure 2). These samples had an average total organic carbon (TOC) of $7.9 \%(4.0 \%$ to $10.7 \%)$ and grain size concentrated in the silt-sized (3.9 $\mu \mathrm{m}$ to 62.5 $\mu \mathrm{m})$ fraction ( $47 \%$ to $71 \%$, average median grain size, $d_{50}$, of $\left.22 \mu \mathrm{m}\right)$. Surface sediments in Juncus roemerianus environments ( $28 \mathrm{~m}$ to $258 \mathrm{~m}$ along the transect) had $\delta^{13} \mathrm{C}$ values between $-27.1 \%$ and $-24.5 \%$ (average $-26.3 \%$ ) and C:N ratios from 14.5 to 22.5 (Figure 2). TOC in these samples averaged $8.3 \%(1.7 \%$ to $15.8 \%)$ and grain size was concentrated in the silt-sized fraction ( $12 \%$ to $71 \%$, median grain size of $49 \mu \mathrm{m}$ ).

At Sand Point, surface sediment samples from $0 \mathrm{~m}$ to $454 \mathrm{~m}$ along the transect in a Juncus roemerianus marsh yielded $\delta^{13} \mathrm{C}$ values from $-28.2 \%$ to $-21.8 \%$ (average $-26.3 \%$ ) and C:N ratios between 11.1 and 41.3 (Figure 2). These samples had an average TOC of $24.6 \%$ (14.5 
$\%$ to $41.3 \%$ ) and a median grain size of $35 \mu \mathrm{m}$ ( $16 \%$ to $74 \%$ silt-sized). Samples at the inland end of the transect ( $454 \mathrm{~m}$ to $471 \mathrm{~m}$ ) in a freshwater upland had $\delta^{13} \mathrm{C}$ values between $-28.8 \%$ and $-26.6 \%$ (average $-27.8 \%$ ) and C:N ratios of 41.6 to 48.8 . TOC in these samples averaged $39.2 \%$ (11.1 \% to $48.8 \%$ ), the median grain size was $83 \mu \mathrm{m}$ with $26 \%$ to $70 \%$ of clastic sediment in the silt-sized fraction.

\section{$4.3 \delta^{13} \mathrm{C}$ and C:N Ratios of Modern Salt-Marsh Plants}

The $\delta^{13} \mathrm{C}$ and $\mathrm{C}: \mathrm{N}$ composition of seven common salt-marsh plants is shown in Figure 3. From 17 specimens at Sand Point, $\delta^{13} \mathrm{C}$ values for Juncus roemerianus ranged from $-28.1 \%$ to -24.9 $\%$ (average $-26.6 \%$ ), C: $\mathrm{N}$ ratios for this species varied from 31.8 to 70.3 (average 45.9 ). Three examples of Distichlis spicata (two from Sand Point and one from Ocracoke) had an average $\delta^{13} \mathrm{C}$ content of $-15.0 \%$ ( $-16.2 \%$ to $-13.1 \%$ ) and average C:N ratio of 48.3 (28.0 to 82.6$)$. A Salicornia sp. plant from Ocracoke yielded a $\delta^{13} \mathrm{C}$ value of $-27.8 \%$ and a C:N ratio of 58 . An Iva fructescens plant from Cedar Island had a $\delta^{13} \mathrm{C}$ value of $-28.3 \%$ and $\mathrm{C}: \mathrm{N}$ ratio of 84.9 . Three samples of Spartina alterniflora had $\delta^{13} \mathrm{C}$ values from $-13.1 \%$ to $-12.6 \%$ (average $-12.9 \%$ ) and C:N ratios that averaged 139 (117.4 to 174.5). Two Spartina cynusoroides plants (Cedar Island and Swan Quarter) had $\delta^{13} \mathrm{C}$ values of $-12.1 \%$ and $-12.8 \%$ with C:N ratios of 70.7 and 343.2. Three Spartina patens plants (one each from Cedar Island, Ocracoke and Swan Quarter NWR) displayed $\delta^{13} \mathrm{C}$ values between $-13.6 \%$ and $-12.9 \%$ and $\mathrm{C}: \mathrm{N}$ ratios of 202.8 to 310.8 .

\subsection{Elevational Distribution of Modern Foraminifera}

At Oregon Inlet, 12 species of foraminifera were recorded in 15 samples along a $250 \mathrm{~m}$ transect (0.02 m to $0.42 \mathrm{~m}$ MTL; Figure 4). Between $0 \mathrm{~m}$ and $28 \mathrm{~m}$ (low marsh, Spartina alterniflora zone), the dominant species was Miliammina fusca (up to $78 \%$ ). High abundances of Arenoparrella mexicana (up to $80 \%$ ) define the assemblage between $38 \mathrm{~m}$ and $223 \mathrm{~m}$. Vegetation in this part of the marsh consisted of mono-specific stands of Juncus roemerianus. 
The landward edge of the transect was represented by Haplophragmoides wilberti (57\%) and was associated with Juncus roemerianus and Iva fructescens.

Three elevation-dependent ecological zones were recognized at Oregon Inlet (Figure 4). Zone Ol-1 extended from $0.02 \mathrm{~m}$ to $0.23 \mathrm{~m} \mathrm{MTL}$ and was defined by high abundances of Miliammina fusca. The Arenoparrella mexicana-dominated part of the marsh formed zone Ol-2 $(0.23 \mathrm{~m}$ to $0.35 \mathrm{~m} \mathrm{MTL}$ ). Foraminiferal assemblages dominated by Haplophragmoides wilberti at elevations from $0.35 \mathrm{~m}$ to $0.42 \mathrm{~m}$ MTL constituted zone OI-3.

At Sand Point, 16 species of foraminifera were recognised at 21 stations across an elevational range from $0.10 \mathrm{~m}$ to $0.53 \mathrm{~m} \mathrm{MTL}$ (Figure 4). Between $0 \mathrm{~m}$ and $73 \mathrm{~m}$, the dominant species was Ammoastuta inepta (up to $36 \%$ ). From $73 \mathrm{~m}$ to $137 \mathrm{~m}$, Miliammina fusca (18 \% to $59 \%$ ) was dominant, Ammoastuta inepta (up to $25 \%$ ) was an important species between $137 \mathrm{~m}$ and 429 m. From 429 m to 448 m, Jadammina macrescens was the dominant species (up to $35 \%$ ) in association with Ammoastuta inepta (up to $29 \%$ ). All of these intervals were associated with Juncus roemerianus. Seven samples, positioned between $448 \mathrm{~m}$ and $471 \mathrm{~m}$ in the freshwater upland contained no foraminifera. Based on foraminiferal assemblages, three elevation-dependent ecological zones were recognized at Sand Point. Between $0.10 \mathrm{~m}$ and $0.18 \mathrm{~m}$ MTL the dominant species was Miliammina fusca (zone SP-1). High proportions of Ammoastuta inepta defined zone SP-2 (0.18 m to $0.30 \mathrm{~m}$ MTL). A Jadammina macrescens-dominated zone (SP-3) extended from $0.23 \mathrm{~m}$ to $0.35 \mathrm{~m} \mathrm{MTL}$. The samples in which foraminifera were absent were positioned above $0.35 \mathrm{~m}$ local MTL.

\section{Discussion}

\subsection{Modern Distribution of Plants and Foraminifera}


Salt-marsh plant communities form elevation-dependent, floral zones that are correlated to the frequency and duration of tidal inundation (e.g. Chapman, 1940; Redfield, 1972). This relationship has been exploited to reconstruct former RSL by identifying the floral zone represented by peat preserved in coastal sedimentary sequences (e.g. Shennan, 1986). We identified two salt-marsh zones on the basis of vascular plants. The low marsh at Oregon Inlet was vegetated by Spartina alterniflora $(-0.10 \mathrm{~m}$ to $0.14 \mathrm{~m} \mathrm{MTL})$ and high marshes at Oregon Inlet and Sand Point were characterized by Juncus roemerianus ( $0.10 \mathrm{~m}$ to $0.42 \mathrm{~m} \mathrm{MTL})$. The limited number and narrow range of elevational zones are a factor of micro-tidal regimes at Oregon Inlet (0.35 $\mathrm{m}$ range) and Sand Point (0.17 $\mathrm{m}$ range).

In areas with larger tides, salt-marsh floral zones exist over an expanded elevational range. On the Atlantic coast of the USA, McKee and Patrick (1988, and references therein) showed that the average elevational range of Spartina alterniflora is $0.93 \mathrm{~m}$ ( $77 \%$ of tidal range) but may be as much as $2.4 \mathrm{~m}$ (86 \% of local tidal range). Adams (1963) showed a strong positive relationship between tidal range and the elevational extent of Spartina alterniflora at sites in North Carolina (up to $0.9 \mathrm{~m} ; 53 \%$ of the tidal range). Similarly, larger tides were associated with an expanded elevational range of Juncus roemerianus (Adams, 1963). In the Cape Fear estuary of North Carolina, Woerner and Hackney (1997) recorded Juncus roemerianus occupying an elevational range of $0.65 \mathrm{~m}$ in a region with a tidal range of $1.43 \mathrm{~m}$. Considerable variation in the elevational distribution of salt-marsh plants exists between sites and attests to the importance of local-scale factors (such as salinity and substrate) in determining floral zonation (e.g. McKee and Patrick, 1988; Woerner and Hackney, 1997). Gehrels (1994) noted differences in the elevational preference of plants between sites and argued that measurements of the elevational range of plant species (including our mean elevational ranges for Spartina alterniflora and Juncus roemerianus) should be considered a minimum because study of additional sites is likely to expand the observed range. 
Foraminifera are more precise sea-level indicators than salt-marsh plants (e.g. Scott and Medioli, 1978, 1980; Gehrels, 1994), although direct comparisons in North America are few. At four sites in Maine, Gehrels (1994) showed that plants occupied wider and more variable elevational zones than salt-marsh foraminifera and concluded that the most precise (narrowest elevational ranges) foraminiferal assemblages were those from high marsh environments at the transition to freshwater upland. Foraminifera at Oregon Inlet and Sand Point also occupied narrower elevational ranges (as small as $0.07 \mathrm{~m}, \mathrm{OI}-3$ ) than plants. In contrast, Patterson et al. (2000) concluded that the elevational range of plant and foraminiferal zones in British Columbia were similar. Jennings and Nelson (1992) showed that tidal flat, low marsh and high marsh zones could be delimited using either plants or foraminifera.

\subsection{Sediment $\delta^{13} \mathrm{C}$ Values as Sea-Level Indicators in North Carolina}

Previous investigations of sediment $\delta^{13} \mathrm{C}$ from salt marshes have alluded to the possibility of reconstructing RSL (e.g. Johnson et al., 2007). The use of $\delta^{13} \mathrm{C}$ and C:N values as sea-level indicators requires that they can be assigned an indicative meaning and identify salt-marsh zones in sedimentary sequences. Although there is not a simple linear correlation between salt-marsh surface elevation and bulk sediment $\delta^{13} \mathrm{C}$ (Figure 5), there is a strong relationship between sediment $\delta^{13} \mathrm{C}$ and plant species making it possible to distinguish between sediments derived from Spartina alterniflora $\left(\mathrm{C}_{4}\right)$ and Juncus roemerianus $\left(\mathrm{C}_{3}\right)$. Three low-marsh samples of surface sediment dominated by Spartina alterniflora at Oregon Inlet had $\delta^{13} \mathrm{C}$ values between $-17.6 \%$ and $-16.2 \%$. In contrast, Juncus roemerianus-dominated environments at Oregon Inlet and Sand Point were characterized by sediment $\delta^{13} \mathrm{C}$ values between $-28.2 \%$ and $-21.8 \%$ (average $-26.3 \%$ ). This difference has been identified elsewhere in North Carolina and at other locations on the Atlantic and Gulf coasts of the USA. In the Pamlico River estuary of North Carolina, Craft et al. (1988) differentiated between sediments derived from $\mathrm{C}_{4}$ plants, Juncus 
roemerianus (-26\%) and forest (-27\%o). Goni and Thomas (2000) identified sediments from forest (-28.8 \%o to $-27.5 \%$ ), Juncus (-23.8 \%o to $-21.4 \%$ ) and Spartina (-20.1\%o to $-17.3 \%$ o) environments in South Carolina. A study by Gebrehiwet et al. (2008) in Georgia, showed a clear difference in $\delta^{13} \mathrm{C}$ values for sediments from Spartina alterniflora and Juncus roemerianus zones. In Louisiana, Chmura et al. (1987) reported $\delta^{13} \mathrm{C}$ values of $-27.8 \%$, $-22.1 \%$ and $16.2 \%$ for freshwater upland, intermediate and salt-marsh sediments, respectively. DeLaune (1986) recorded sediments derived from Spartina alterniflora in Louisiana as having an average $\delta^{13} \mathrm{C}$ value of $-16.5 \%$. Choi et al. (2001) showed that Juncus roemerianus salt-marsh sediments in Florida had an average $\delta^{13} \mathrm{C}$ value of $-27 \%$. In Massachusetts, Middleburg et al. (1997) distinguished between sediments from Spartina-dominated and more brackish environments.

Although $\delta^{13} \mathrm{C}$ values from bulk-organic sediments differentiate Spartina alterniflora and Juncus roemerianus environments, $\delta^{13} \mathrm{C}$ values associated with other plants on North Carolina salt marshes must be considered (Figure 3). Three specimens (two from Sand Point and one from Ocracoke) of Distichlis spicata (a high marsh, $C_{4}$ plant) yielded an average $\delta^{13} \mathrm{C}$ value of -15.0 $\%$ ( $-16.1 \%$ to $-13.1 \%$ ), which is comparable to measurements from other studies (e.g. Ungar, 1991; Chmura and Aharon, 1995). Spartina patens is also a $\mathrm{C}_{4}$ plant with a patchy distribution in high marshes (Adams, 1963). Three examples (from Cedar Island, Ocracoke and Swan Quarter) had an average $\delta^{13} \mathrm{C}$ value of $-13.2 \%$. According to Chmura and Aharon (1995) this species has $\delta^{13} \mathrm{C}$ values of $-13.6 \%$ to $-11.7 \%$. Spartina cynusoroides is a low salinity, high marsh plant $\left(\mathrm{C}_{4}\right)$; two examples from Cedar Island had $\delta^{13} \mathrm{C}$ values of $-12.6 \%$ and $-12.8 \%$. Chmura and Aharon (1995) listed Spartina cynusoroides as having a $\delta^{13} \mathrm{C}$ range of $-13.6 \%$ to $-12.0 \%$. Distichlis spicata, Spartina cynusoroides and Spartina patens have plant tissue $\delta^{13} \mathrm{C}$ values that are comparable to that of Spartina alterniflora but they are found in high rather than low marshes. The problem that the wide distribution of these species presents for RSL reconstruction in the southeastern USA was highlighted by Chmura and Aharon (1995), who 
recognized that high and low marsh $\mathrm{C}_{4}$ plants may be indistinguishable on the basis of plant or sediment $\delta^{13} \mathrm{C}$ and $\mathrm{C}: \mathrm{N}$ values. Regional differences in the distribution of $\mathrm{C}_{4}$ plants and $\delta^{13} \mathrm{C}$ values must be considered before making paleoenvironmental interpretations (Chmura and Aharon, 1995).

In the same way, overlap of sediment $\delta^{13} \mathrm{C}$ values from high marsh (Juncus roemerianus) and freshwater upland zones at Oregon Inlet and Sand Point makes differentiating them difficult. The average $\delta^{13} \mathrm{C}$ of bulk sediments differs only slightly (-26.3\%o for Juncus roemerianus and $-27.8 \%$ for freshwater upland zones) and their ranges overlap. Whereas Juncus roemerianus sediments displayed $\delta^{13} \mathrm{C}$ values from $-28.2 \%$ to $-21.8 \%$, freshwater upland sediments ranged from $-28.1 \%$ to $-26.8 \%$. Several studies have distinguished these environments using sediment $\delta^{13} \mathrm{C}$ values (e.g. Chmura et al., 1987; Craft et al., 1988; Chmura and Aharon, 1995; Goni and Thomas, 2000), but results from this study show that this distinction is difficult.

\subsection{Bulk Sediment and Vegetation $\delta^{13} C, C: N$}

We investigated whether surface sediments adequately represented the dominant type of vegetation at the time of accumulation by comparing $\delta^{13} \mathrm{C}$ and $\mathrm{C}: \mathrm{N}$ values of Juncus roemerianus plants to the surface sediment they were collected from at Sand Point (Figure 6). The average difference between plant and surface sediments was $0.8 \%$, although a single sample recorded a difference of $4 \%$ (Figure 6a). This change is not sufficient to cause samples from Juncus roemerianus zones to be mis-classified (figure 3) and is similar to differences reported elsewhere (e.g. Chmura et al., 1987). In North Carolina, Craft et al. (1988) concluded that the $\delta^{13} \mathrm{C}$ of Juncus roemerianus sediments (-23.8\%) was similar to plant material $(-26.0$ $\%$ ). Goni and Thomas (2000) showed little difference between $\delta^{13} \mathrm{C}$ from Juncus roemerianus plants (-24.9\%o) and sediments (-23.8\%o). Similarly, Johnson and Calder (1973) and Hackney 
and Haines (1980) reported little difference between sediment and plant $\delta^{13} \mathrm{C}$ values in Juncus roemerianus zones.

In contrast, there is a clear difference between $\delta^{13} \mathrm{C}$ of Spartina alterniflora plants and surface sediments (Figure 6c). At Oregon Inlet, low marsh, Spartina alterniflora sediments had $\delta^{13} \mathrm{C}$ values from $-17.6 \%$ to $-16.2 \%$ (Figures 2 and 6c), whilst plants (from Ocracoke, Swan Quarter NWR and Cedar Island) had less depleted values ranging from $-13.1 \%$ to $-12.6 \%$ (Figures 3 and 6c). Spartina alterniflora-derived sediments commonly have more negative $\delta^{13} \mathrm{C}$ values than living plant tissue from this species. In North Carolina, Craft et al. (1988) showed that Spartina alterniflora plants had an average $\delta^{13} \mathrm{C}$ value of $-12.0 \%$, whilst corresponding surface sediments had an average $\delta^{13} \mathrm{C}$ value of $-18.4 \%$. Goni and Thomas (2000) reported changes of $4.0 \%$ to $6.8 \%$ between Spartina alterniflora tissue and sediment. Chmura et al. (1987) found that sediments were depleted by up to $4 \%$ in comparison with plant material. In Georgia, Fogel et al. (1989) recorded sediments that were up to $5.5 \%$ more depleted than Spartina alterniflora plants. Changes in $\delta^{13} \mathrm{C}$ values between plants and bulk-organic sediment are probably not sufficiently large to cause Spartina alterniflora environments to be misidentified and assigned an erroneous indicative meaning (Figures 3 and 5).

Differences between plant and sediment $\delta^{13} \mathrm{C}$ values may be caused by decomposition during accumulation of organic material (Lamb et al., 2006). According to Ember et al. (1987), Spartina alterniflora values for plant tissues and bulk sediments are different due to fractionation of organic carbon within the living plant and the subsequent preferential breakdown of cellulose over lignin. Lignin $\delta^{13} \mathrm{C}$ is typically more depleted than cellulose $\delta^{13} \mathrm{C}$ or the $\delta^{13} \mathrm{C}$ from the plant as a whole (Vane et al., 2003; Lamb et al., 2006). During decomposition, lignin is preferentially concentrated in surface sediments resulting in a relative depletion of sediment $\delta^{13} \mathrm{C}$ (Chmura et al., 1987; Chmura and Aharon, 1995: Mallamud-Roam and Ingram, 2001). Alternatively, $\delta^{13} \mathrm{C}$ of 
bulk sediments may differ from plant tissue due to allochthonous carbon inputs. Sources include fluvial or marine particulate and dissolved organic carbon (Lamb et al., 2006). Low marsh settings are most likely to be inundated by astronomical tides and storms, whilst high marsh settings are more likely to receive inputs of terrestrial organic carbon. However, Chmura et al. (1987) concluded that local plants were the main source of organic carbon in salt marshes and that sediment $\delta^{13} \mathrm{C}$ values were representative of the dominant vegetation. On longer timescales, two studies in the San Francisco Bay estuary (Byrne et al., 2001; Malamud-Roam and Ingram, 2004) showed that salt-marsh zones could be reliably identified in sediments more than 3000 years after deposition, whilst Lamb et al. (2007) compared downcore $\delta^{13} \mathrm{C}$ values in sediments up to 3300 years old to foraminiferal assemblages and concluded that there was little fractionation.

$\mathrm{C}: \mathrm{N}$ ratios are strongly influenced by post-depositional processes. At Sand Point, organic sediment $\mathrm{C}: \mathrm{N}$ ratios were lower than those recorded in plants (Figure 6b). Goni and Thomas (2000) demonstrated the tendency for forest, Juncus- and Spartina-derived sediments to have comparable $\mathrm{C}: \mathrm{N}$ ratios despite large differences in the $\mathrm{C}: \mathrm{N}$ ratio of source vegetation. The similarity in bulk sediment $\mathrm{C}: \mathrm{N}$ ratios is a consequence of nitrogen retention coupled with carbon loss through oxidation of plant material during decomposition (Ember et al., 1987; Chmura et al., 1987). The size of this change makes it difficult to reconstruct the salt-marsh zone in which bulkorganic sediments formed because C:N ratios from different zones converge during early diagenesis, rendering them unsuitable for reconstructing former RSL.

\subsection{Implications for Reconstructing Holocene Relative Sea Level}

We examined the utility of sediment $\delta^{13} \mathrm{C}$ as a sea-level indicator by reconstructing RSL from published sea-level data. Horton et al. (2009) compiled a database of validated North Carolina Holocene sea-level index points and data points that constrain the maximum and minimum 
elevation of RSL (freshwater and marine limiting points). We considered a sub-sample of eight sea-level index points and three freshwater limiting points. Estimates of the indicative meaning were based on the elevational range of modern salt-marsh plants and recognition of these floral zones from the analogy between modern and fossil sediment $\delta^{13} \mathrm{C}$ values (Table 1; Figure 7).

Sediment $\delta^{13} \mathrm{C}$ values from $-26.7 \%$ to $-21.8 \%$ were considered to represent a Juncus roemerianus floral zone. Freshwater upland zones are identified by sediment $\delta^{13} \mathrm{C}$ values more depleted than $-28.2 \%$. Sediments with intermediate values could be from either zone and are assigned an indicative meaning reflecting this uncertainty. These values may only be appropriate for the study region (Chmura and Aharon, 1995) and additional studies from mesoand macrotidal regions incorporating high, low and pioneer marshes and tidal flat environments would be appropriate and necessary for efforts to reconstruct RSL from other regions. From leveling of floral zone boundaries at Oregon Inlet and Sand Point we assigned Spartina alterniflora zones an indicative meaning of $0.02 \mathrm{~m} \mathrm{MTL} \pm 0.12 \mathrm{~m}$ and Juncus roemerianus zones were assigned an indicative meaning of $0.26 \mathrm{~m} \mathrm{MTL} \pm 0.16 \mathrm{~m}$. In the case of $\mathrm{C}_{4}$ plants, sediment $\delta^{13} \mathrm{C}$ values cannot distinguish between specific plants, therefore we gave them an indicative meaning of $0.16 \mathrm{mMTL} \pm 0.26 \mathrm{~m}$, because they can occupy the full elevational range of salt-marshes in North Carolina. For comparison, alternative estimates of the indicative meaning were produced using a transfer function based upon the modern distribution of foraminifera in the Albemarle-Pamlico estuarine system (Kemp et al., 2009). This statistical technique has become common-place for reconstructing RSL from salt-marshes (Gehrels, 2007).

Sea-level index points 1 to 3 (table one) had $\delta^{13} \mathrm{C}$ values between $-25.5 \%$ and $-21 \%$ and represent Juncus roemerianus zones. Foraminiferal data provided estimated reference water levels (RWL) between $0.20 \mathrm{~m}$ and $0.29 \mathrm{~m} \mathrm{MTL}$ with an average indicative range (IR) of \pm 0.05 
$\mathrm{m}$. Index point 4 was identified as being from either a Juncus roemerianus or freshwater upland zone because it had an intermediate $\delta^{13} \mathrm{C}$ value of $-26.67 \%$. However, foraminifera indicated that it formed in brackish rather than freshwater conditions and was assigned an indicative meaning of $0.19 \mathrm{~m} \mathrm{MTL} \pm 0.05 \mathrm{~m}$. Sea-level index points 5 to 8 had $\delta^{13} \mathrm{C}$ values typical of $\mathrm{C}_{4}$ vegetation (Table 1) and were assigned an indicative meaning spanning the entire elevational range of salt-marsh vegetation (Figure 7; Table 1). Foraminifera associated with these samples estimated RWLs from $0.12 \mathrm{~m}$ to $0.25 \mathrm{~m} \mathrm{MTL}$ with an average IR of $\pm 0.05 \mathrm{~m}$ (Figure 7; Table 1). The RWL estimated for sea-level index points using $\delta^{13} \mathrm{C}$ values are not significantly different from transfer function estimates. Foraminifera are more precise sea-level indicators that are able to estimate the indicative meaning of samples from all salt-marsh zones. In contrast, sediment $\delta^{13} \mathrm{C}$ values are restricted to describing broad changes in RSL by identifying sea-level index points (with large uncertainties) derived from salt marshes dominated by $\mathrm{C}_{4}$ vegetation.

Freshwater limiting points are derived from supra-tidal environments and provide an important constraint on the upper limit of former RSL (Shennan, 2007). We considered three samples that were defined as freshwater limiting points by Horton et al. (2009) on the basis of diatom and pollen assemblages and an absence of foraminifera (Mallinson et al., 2005; Culver et al., 2008). Using this microfossil evidence, we recognized samples 9, 10 and 11 as freshwater limiting points (Table 1, Figure 7). The reported $\delta^{13} \mathrm{C}$ values of these samples were $-28.0 \%$, $-27.21 \%$ o and $-26.35 \%$. Due to the difficulty in separating freshwater upland and Juncus roemerianusdominated zones, samples with $\delta^{13} \mathrm{C}$ values between $-28.5 \%$ and $-26.0 \%$ may represent either zone and were assigned an indicative meaning reflecting this uncertainty (Table 1, Figure 7).

\subsection{Refinement of $\delta^{13} \mathrm{C}$ and $\mathrm{C}: \mathrm{N}$ as Sea-Level Indicators}

A key issue in using bulk-organic sediment $\delta^{13} \mathrm{C}$ and $\mathrm{C}: \mathrm{N}$ values to reconstruct sea-level is the difficulty in identifying salt-marsh zones dominated by a particular plant species. We have 
shown that it is possible to recognize sediments derived from $\mathrm{C}_{3}$ or $\mathrm{C}_{4}$ zones and that the application of this approach is limited by the broad elevational tolerance of $\mathrm{C}_{4}$ plants and problems distinguishing between freshwater upland and salt-marsh $\mathrm{C}_{3}$ plant zones. Measured values of $\delta^{13} \mathrm{C}$ and $\mathrm{C}: \mathrm{N}$ in bulk sediment incorporate the influence of allochthonous material and plant decomposition, which may distort the signal from the dominant plant community.

One approach that might overcome these difficulties is to analyze $\delta^{13} \mathrm{C}$ values from a specific fraction of the sediment, which may include organic components from only the dominant plant community. For example, some components may consist of the fraction that is soluble in common organic solvents (lipids, pigments, flavonoids) or the insoluble fraction such as lignin, tannins and structural polysaccharides (Stephenson et al., 2005, 2008). Molecular level studies of lipids and major cell wall polymers (e.g. lignin, tannins and structural polysaccharides) may be potential indicators of plant source and vegetation zones (Benner et al., 1991; Goni et al., 2000; Herenes, 2001). In particular, lignin is well preserved in salt-marsh sediments (Vane et al., 2003, 2005, 2006; Lamb et al., 2007). Analytical pyrolysis, tetra alkyl chemolysis, and alkaline $\mathrm{CuO}$ oxidation are frequently applied to cleave bonds within the lignin structure and yield monomers that can be separated and identified by gas-chromatography massspectrometry (GC/MS). Assuming the distribution and quantity of monomers can be related to plant species, they may be used to identify the dominant type of vegetation in sediments (Goni et al., 2000; Vane, 2003)

A second possible approach is to analyze sediment $\delta^{13} \mathrm{C}$ values retained in particular organic compounds, namely $n$-alkanes. Compound-specific isotopic analysis (CSIA) of long chain $n$ alkanes $n \mathrm{C}_{21}-n \mathrm{C}_{33}$ in salt-marsh sediments has been used to distinguish specific plant communities in northeastern USA (Wang et al., 2003 in Massachusetts; Tanner et al., 2007 in Maine). Gas chromatography isotope-ratio mass spectrometry (GC-IRMS) of individual $n$ - 
alkanes extracted from living plants showed that the $n \mathrm{C}_{27}$ and $n \mathrm{C}_{29}$ homologues were abundant in all plants and could distinguish Spartina alterniflora and Spartina patens $\left(\mathrm{C}_{4}\right)$ from $\mathrm{C}_{3}$ plants such as Juncus spp. based upon a 3.0 to $6.4 \%$ minimum difference (Tanner et al., 2007). However, other homologues such as $n \mathrm{C}_{31}$ were not present in all plants and are variable in absolute concentration; high concentrations of compounds are generally considered a prerequisite for GC/IRMS analysis. Although detailed molecular techniques show considerable promise as tools to identify vegetation zones, they are presently more timing consuming and costly than carbon isotope analysis of bulk-organic sediment.

\section{Conclusions}

We investigated the use of bulk-organic sediment geochemistry as a means of identifying floral zones that could be used as sea-level indicators. $\delta^{13} \mathrm{C}$ values and $\mathrm{C}: \mathrm{N}$ ratios were measured along modern transects of surface sediment at Oregon Inlet and Sand Point (North Carolina, USA) and compared to elevational zones defined by plants and foraminiferal assemblages. Sediment $\delta^{13} \mathrm{C}$ values do not have a simple linear correlation with elevation but can distinguish zones dominated by Spartina alterniflora $\left(\mathrm{C}_{4}\right.$ photosynthetic pathway, $\delta^{13} \mathrm{C}$ values from $-17.6 \%$ to $-16.2 \%$ ) and Juncus roemerianus $\left(C_{3}\right.$ photosynthetic pathway $\delta^{13} \mathrm{C}$ values from $-28.2 \%$ to $-21.8 \%$ ). The elevational range of the two floral zones at these sites reflects the microtidal nature of the region. Comparison between the geochemical characteristics of Juncus roemerianus plants and surface sediments revealed that there is little change in $\delta^{13} \mathrm{C}$ values during diagenesis (average $0.8 \%$ ). Based on three samples, the difference between Spartina alterniflora plants and sediment was approximately $4 \%$. In contrast, C:N ratios are significantly altered during early diagenesis, causing low marsh, high marsh and freshwater upland sediments to have similar values. 
The elevational distribution of common salt-marsh plants was used to estimate the indicative meaning of sea-level index points using sediment $\delta^{13} \mathrm{C}$ values to identify floral zones. The use of sediment $\delta^{13} \mathrm{C}$ values as independent sea-level indicators is complicated in North Carolina by $\mathrm{C}_{4}$ plants (such as the low marsh species Spartina alterniflora and high marsh species including Distichlis spicata, Spartina cynusoroides and Spartina patens) occupying the full elevational range of salt-marsh environments. Uncertainty in differentiating between sediments derived from these plant species on the basis of $\delta^{13} \mathrm{C}$ values results in a large indicative range. Furthermore, Juncus roemerianus-dominated sediments from high marsh settings cannot be adequately distinguished from the sediment of freshwater upland zones.

In instances where microfossil assemblages are absent from the fossil record or have undergone significant post-depositional modification, $\delta^{13} \mathrm{C}$ values may help distinguish the sediments of former high and low marshes. Refined analysis using $\delta^{13} \mathrm{C}$ values from specific fracations of sediment may increase the possible precision of RSL reconstructions from geochemical proxies preserved in bulk-organic sediments by recognizing particular plant species. 


\section{Acknowledgements}

C.H. Vane publishes with permission of the Executive Director, British Geological Survey. The authors thank C. Kendrick and M. Leng for stable carbon isotope measurements (National Isotope Geosciences Laboratory, UK). This research is part of NOAA Coastal Ocean Program grant and the North Carolina Coastal Geology Cooperative Program. We thank United States Geological Survey cooperative agreement award 02ERAG0044 and National Science Foundation award EAR-0717364. This paper is a contribution to IGCP Project 495, "Quaternary LandOcean interactions: Driving Mechanisms and Coastal Responses". A.C. Kemp acknowledges the 2007 Garry Jones Memorial Award (North American Micropaleontology section, SEPM), a University of Pennsylvania summer stipend in Paleontology, and a Geological Society of America graduate student research grant. Andrea Hawkes, Simon Engelhart, Matthew Wright, Candace Grand-Pre and D. Reide Corbett are thanked for their assistance in the field. Arthur Johnson, Alain Plante, Frederick Scatena and David Vann (University of Pennsylvania) are thanked for their insightful comments on this manuscript. This manuscript benefited from thorough and considered reviews from Alan Nelson and Jerry Lloyd and the editorial assistance of Joe Mason. 


\section{Table One}

The indicative meaning of sea-level data estimated from $\delta^{13} \mathrm{C}$ values and foraminifera

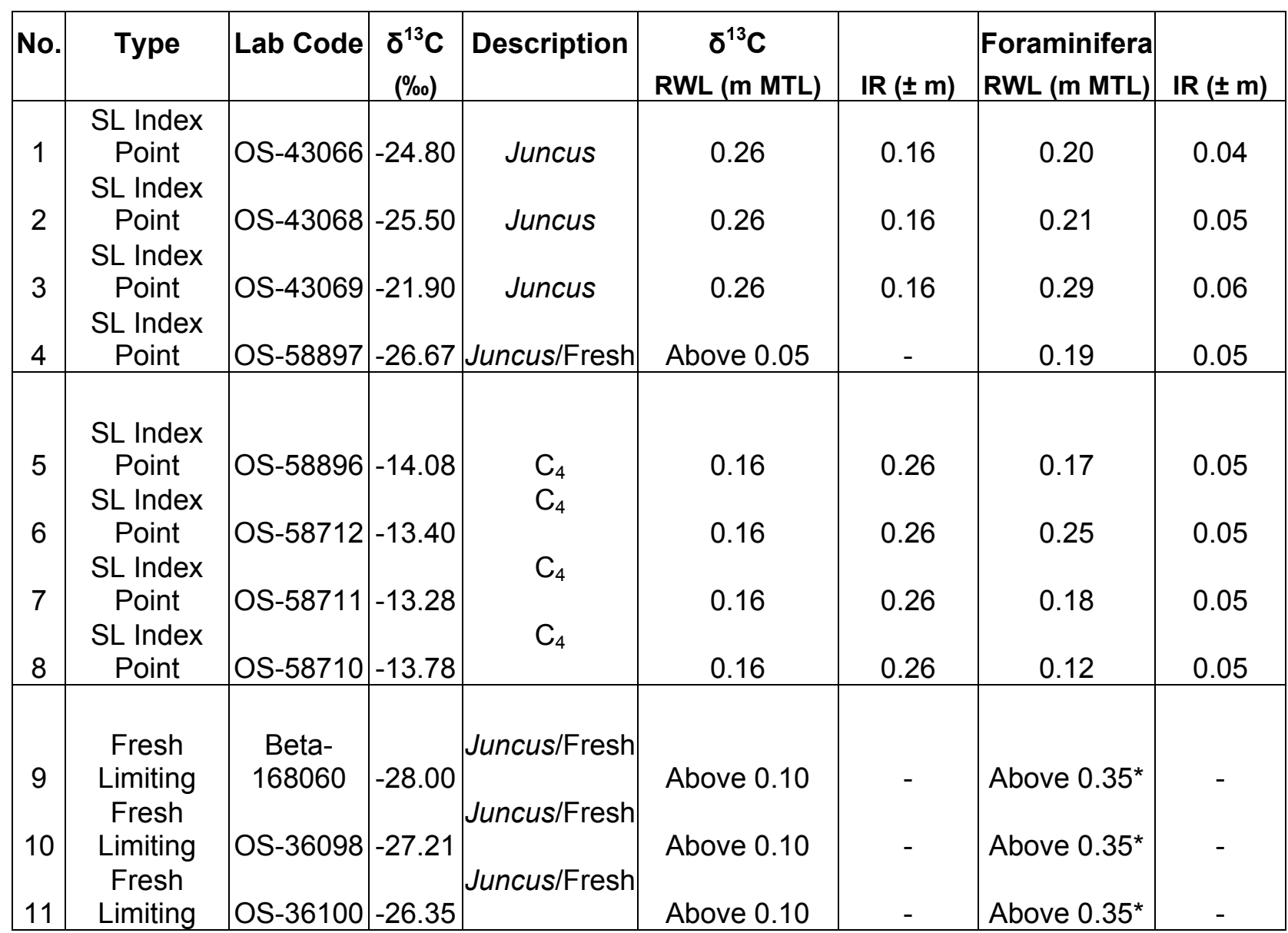

Interpretation of Holocene sea-level index points and freshwater limiting points. For each sample, a Reference Water Level (RWL) and Indicative Range (IR) were estimated using sediment $\delta^{13} \mathrm{C}$ values and a foraminifera-based transfer function. * The RWL assigned to freshwater limiting points reflects the quantitative diatom evidence (with an absence of foraminifera) reported in Horton et al. (2009). 


\section{Figure Captions}

Figure 1: (A) Location of the Oregon Inlet and Sand Point sites in coastal North Carolina. Foraminifera, $\delta{ }^{13} \mathrm{C}$ and $\mathrm{C}: \mathrm{N}$ were measured in samples along two transects (dashed lines, $X$ to $\mathrm{Y}$ ) at (B) Oregon Inlet and (C) Sand Point. Sample elevations were established by leveling to geodetic benchmarks. (D) The components of indicative meaning, which defines the relationship between a sea-level indicator and elevation in the tidal frame. HAT = Highest Astronomical Tide, MHHW = Mean Higher High Water, MTL = Mean Tide Level.

Figure 2: Pattern of $\delta^{13} \mathrm{C}, \mathrm{C}: \mathrm{N}$, Total Organic Carbon (TOC) and grain size of bulk-organic sediment along modern transects at Oregon Inlet and Sand Point. Median grain size $\left(d_{50}\right)$ in $\mu \mathrm{m}$ is shown by dots and percentage clay by volume is shown by vertical grey bars. Solid circles show samples collected in Juncus roemerianus environments; at Oregon Inlet samples from the Spartina alterniflora (SA) low marsh are shown as hollow circles; at Sand Point these represent samples from the freshwater upland.

Figure 3: $\delta^{13} \mathrm{C}$ and $\mathrm{C}: \mathrm{N}$ values measured from modern specimens of common salt-marsh plants and bulk-organic sediment in North Carolina. Grey boxes represent the range of values thought to be representative of $\mathrm{C}_{3}$ and $\mathrm{C}_{4}$ plants (after Lamb et al., 2006). Dashed lines are the average $\delta^{13} \mathrm{C}$ of $\mathrm{C}_{4}\left(-12 \%\right.$; Schlesinger, 1997) and $\mathrm{C}_{3}(-27 \%$; Choi et al., 2001) plants.

Figure 4: (A) Distribution of samples, vegetation and dominant salt-marsh foraminifera along modern transects at Oregon Inlet and Sand Point. Only species that dominant foraminiferal zones are presented. Solid circles show samples collected in Juncus roemerianus environments; at Oregon Inlet samples from the Spartina alterniflora (SA) low marsh are shown as hollow circles; at Sand Point these represent samples from the freshwater upland. Elevationdependent ecological zones of foraminifera at Oregon Inlet (OI) and Sand Point (SP) defined by cluster analysis are presented for each site.

Figure 5: (A) The relationship between surface sediment $\delta^{13} \mathrm{C}$ values and elevation at Oregon Inlet and Sand Point. Samples are differentiated on the basis of the floral environment from which they were collected. (B) The indicative meaning assigned to Juncus roemerianus (Jr), Spartina alterniflora ( $\mathrm{Sa}$ ), $\mathrm{C}_{4}$ and freshwater upland vegetation zones based on levelling of the boundaries between floral zones. The elevational ranges are a minimum estimate.

Figure 6: Comparison of plant and bulk sediment $\delta^{13} \mathrm{C}$ values $(A)$ and $C: N$ ratios $(B)$ from a Juncus roemerianus-dominated salt marsh at Sand Point. (C) Non-paired samples of Spartina alterniflora plants (open circles; Ocracoke, Swan Quarter and Cedar Island) and sediments (filled circles; Oregon Inlet).

Figure 7: Indicative meanings of eight sea-level index points and three freshwater limiting points from a database of North Carolina Holocene sea-level data. Estimates of indicative meaning were made on the basis of sediment $\delta^{13} \mathrm{C}$ values (grey boxes) and a foraminiferabased transfer function (white boxes). Hashed boxes represent the inference made from diatom evidence that the samples were formed in a freshwater upland environment. Arrows represent show that estimates associated with freshwater limiting points are minimums. MTL $=$ Mean Tide Level. 


\section{References}

Adams, D.A. 1963. Factors influencing vascular plant zonation in North Carolina salt marshes. Ecology 44, 445-456.

Allen, J.R.L. and Thornley, D.M. 2004. Laser granulometry of Holocene estuarine silts: effects of hydrogen peroxide treatment. The Holocene 14, 290-295.

Benner, R., Fogel, M.L. and Sprague, E.K. 1991. Diagenesis of below ground Spartina alterniflora in salt-marsh sediments. Limnology and Oceanography 36, 1358-1374.

Brinson, M.M. 1991: Ecology of a non-tidal brackish marsh in coastal North Carolina. National Wetlands Research Center open file report 91-03.

Byrne, R., Ingram, B.L., Starrat, S., Malamud-Roam, F., Collins, J.N and Conrad, M.E. 2001. Carbon-isotope, diatom and pollen evidence for late Holocene salinity change in a brackish marsh in the San Francisco Estuary. Quaternary Research 55, 66-76.

Chapman, V.J. 1940. Succession on New England salt marshes. Ecology 21, 279-282.

Chapman, V.J. 1960: Salt Marshes and Salt Deserts of the World. Interscience Publishers.

Chmura, G.L. and Aharon, P. 1995. Stable carbon isotope signatures of sedimentary carbon in coastal wetlands as indicators of salinity regime. Journal of Coastal Research 11, 124-135.

Chmura, G.L., Aharon, P., Socki, R.A. and Abernethy, R. 1987. An inventory of ${ }^{13} \mathrm{C}$ abundances in coastal wetlands of Louisiana, USA: vegetation and sediments. Oecologia 74, 264-271.

Choi, Y., Wang, Y., Hsieh, Y.P. and Robinson, L. 2001. Vegetation succession and carbon sequestration in a coastal wetland in northwest Florida: evidence from carbon isotopes. Global Biogeochemical Cycles 15, 311-319.

Craft, C.B., Broome, S.W., Seneca, E.D. and Showers, W.J. 1988. Estimating sources of soil organic matter in natural and transplanted estuarine marshes using stable isotopes of carbon and nitrogen. Estuarine, Coastal and Shelf Science 26, 633-641.

Culver, S.J. and Horton, B.P. 2005. Infaunal marsh foraminifera from the Outer Banks, North Carolina, USA. Journal of Foraminiferal Research 35, 148-170.

Culver, S.J., Farrell, K., Mallinson, D.J., Horton, B.P., Willard, D.A., Thieler, E.R., Riggs, S.R., Synder, S.W., Wehmiller, J.F., Bernhardt, C.E. and Hillier, C. 2008. Micropaleontologic record of late Pliocene and Quaternary paleoenvironments in the northern Albemarle Embayment, North Carolina, USA. Palaeogeography, Palaeoecology, Palaeoclimatology 264, 54-77.

de Rijk, S. 1995: Agglutinated foraminifera as indicators of salt marsh development in relation to late Holocene sea-level rise (Great Marshes at Barnstable, Massachusetts). Febo, Utrecht, The Netherlands. 
DeLaune, R.D. 1986. The use of $\delta^{13} \mathrm{C}$ signature of C-3 and C-4 plants in determining past depositional environments in rapidly accreting marshes of the Mississippi River deltaic plain, Louisiana, U.S.A. Chemical Geology 59, 315-320.

Edwards, R.J. 2007: Sea level studies: low energy coasts sedimentary indicators. In Elias, S.A. (Ed), Encyclopaedia of Quaternary Science, Elsevier, 2994-3006.

Eleuterius, L.N. 1976. The distribution of Juncus roemerianus in the salt marshes of North America. Chesapeake Science 17, 289-292.

Ember, L.M., Williams, D.F. and Morris J.T. 1987. Processes that influence carbon isotope variations in salt-marsh sediments. Marine Ecology Progress Series 36, 33-42.

Fatela, F. and Taborda, R. 2002. Confidence limits of species proportions in microfossil assemblages. Marine Micropaleontology 45, 169-174.

Fogel, M.L., Sprague, E.K., Gize, A.P. and Frey, R.W. 1989. Diagenesis of organic matter in Georgia salt marshes. Estuarine, Coastal and Shelf Science 28, 211-230.

Gebrehiwet, T., Koretsky, C.M. and Krishnamurthy, R.V. 2008. Influence of Spartina and Juncus on saltmarsh sediments III. Organic geochemistry. Chemical Geology 255, 114-119.

Gehrels, W.R. 1994. Determining relative sea-level change from salt-marsh foraminifera and plant zones on the coast of Maine, USA. Journal of Coastal Research 10, 990-1009.

Gehrels, W.R. 2000. Using foraminiferal transfer functions to produce high-resolution sea-level records from salt-marsh deposits, Maine, USA. The Holocene 10, 367-376.

Gehrels, W.R. 2007: Sea level studies: microfossil reconstructions. In Elias, S.A., editor, Encyclopaedia of Quaternary Science, Elsevier, 3015-3024.

Goldstein, S.T. and Harben, E.B. 1993. Taphofacies implications of infaunal foraminiferal assemblages in a Georgia saltmarsh, Sapelo Island. Micropaleontology 39, 53-62.

Goldstein, S.T. and Watkins, G.T. 1999. Taphonomy of salt marsh foraminifera: an example from coastal Georgia. Palaeogeography, Palaeoclimatology, Palaeoecology 149, 103-114.

Goni, M.A. and Thomas, K.A. 2000. Sources and transformations of organic matter in surface soils and sediments from a tidal estuary. Estuaries 23, 548-564.

Goni, M.A., Yunker, M.B., MacDonald, R.W. and Eglinton, T.I. 2000. The supply and preservation of ancient and modern components of organic carbon in the Canadian Beaufort Shelf of the Arctic Ocean. Marine Chemistry 93, 53-73.

Hawkes, A.D., Bird, M., Cowie, S., Grundy-Warr, C., Horton, B.P., Tan Shau Hwai, A., Law, L., Macgregor, C., Nott, J., Eong Ong, J., Rigg, J., Robinson, R., Tan-Mullins, M., Tiong Sa, T. and Zulfigar, Y. 2007. The sediments deposited by the 2004 Indian Ocean tsunami along the Malay-Thai Peninsula. Marine Geology 242, 169-190.

Hackney, C.T. and Haines, E.B. 1980. Stable carbon isotope composition of fauna and organic matter collected in a Mississippi estuary. Estuarine and Coastal Marine Science 10, 703-708. 
Hess, K.W., Spargo, E., Wong, A., White, S.A. and Gill, S.K. 2005. VDatum for Coastal North Carolina: Tidal Datums, Marine Grids, and Sea Surface Topography. U.S. Department of Commerce, National Oceanic and Atmospheric Administration, Silver Spring, Maryland, NOAA Technical Report NOS CS 21.

Hippensteel, S.P., Martin, R.E., Nikitina, D. and Pizzuto, J.E. 2000. The formation of Holocene marsh foraminiferal assemblages, Middle Atlantic coast, USA: implications for Holocene sea-level change. Journal of Foraminiferal Research 30, 272-293.

Horton, B.P. and Edwards, R.J. 2006. Quantifying Holocene sea-level change using intertidal foraminifera: Lessons for the British Isles. Cushman Foundation for Foraminiferal Research, Special Publication 40, 97p.

Horton, B.P., Peltier, W.R., Culver, S.J., Drummond, R., Engelhart, S.E., Kemp, A.C., Mallinson, D., Thieler, E.R., Riggs, S.R. and Ames, D.V. 2009. Holocene sea-level change along the North Carolina coastline and their implications for glacial isostatic adjustment models. Quaternary Science Reviews 28, 1725-1736.

Jennings, A.E. and Nelson, A.R. 1992. Foraminiferal assemblage zones in Oregon tidal marshes - relation to marsh floral zones and sea level. Journal of Foraminiferal Research 22, 13-29.

Jonasson, K.E. and Patterson, R.T. 1992. Preservation potential of salt marsh foraminifera from the Fraser River Delta, British Columbia. Micropaleontology 38, 289-301.

Johnson, B.J., Moore, K.A., Lehmann, C., Bohlen, C. and Brown, T.A. 2007. Middle to late Holocene fluctuations of $\mathrm{C}_{3}$ and $\mathrm{C}_{4}$ vegetation in a northern New England salt marsh, Sprague Marsh, Phippsburg, Maine. Organic Geochemistry 38, 394-403.

Johnson, R.W. and Calder, J.A. 1973. Early diagenesis of fatty acids and hydrocarbons in a salt marsh environment. Geochimica et Cosmochimica Acta 37, 1943-1955.

Kemp, A.C., Horton, B.P. and Culver, S.J. 2009. Distribution of modern salt-marsh foraminifera in the Albemarle - Pamlico Estuarine System of North Carolina, USA: Implications for sea-level research. Marine Micropaleontology 72, 222-238.

Lamb, A.L., Wilson, G.P. and Leng, M.J. 2006. A review of coastal palaeoclimate and relative sea-level reconstructions using $\delta^{13} \mathrm{C}$ and $\mathrm{C} / \mathrm{N}$ ratios in organic material. Earth-Science Reviews $75,29-57$.

Lamb, A.L., Vane, C.H., Wilson, G.P., Rees, J.G. and Moss-Hayes, V.L. 2007. Assessing $\delta^{13} \mathrm{C}$ and $\mathrm{C} / \mathrm{N}$ ratios from organic material archived in cores as Holocene sea level and palaeoenvironmental indicators in the Humber Estuary, UK. Marine Geology 244, 109-128.

Malamud-Roam, F. and Ingram, B.L. 2001. Carbon isotopic compositions of plants and sediments of tide marshes in the San Francisco estuary. Journal of Coastal Research 17, 1729. 
Malamud-Roam, F. and Ingram, B.L. 2004. Late Holocene $\delta^{13} \mathrm{C}$ and pollen records of paleosalinity from tidal marshes in the San Francisco Bay estuary, California. Quaternary Research 62, 134-145.

Mallinson, D., Riggs, S.R., Thieler, E.R., Culver, S., Farrell, K., Foster, D.S., Corbett, D.R., Horton, B.P. and Wehmiller, J.F. 2005. Late Neogene and Quaternary evolution of the northern Albemarle Embayment (mid-Atlantic continental margin, USA). Marine Geology 217, 97-117.

McKee, K.L. and Patrick, W.H. 1988. The relationship of Smooth Cordgrass (Spartina alterniflora) to tidal datums: a review. Estuaries 11, 143-151.

Middleburg, J.J., Nieuwenhuize, J., Lubberts, R.K. and van de Plassche, O. 1997. Organic carbon isotope systematics of coastal marshes. Coastal, Estuarine and Shelf Science 45, 681687.

Murray, J.W. and Alve, E. 2000. Major aspects of foraminiferal variability (standing crop and biomass) on a monthly scale in an intertidal zone. Journal of Foraminiferal Research 30, 177191.

Ozarko, D.L., Patterson, R.T. and Williams, H.F.L. 1997. Marsh foraminifera from Nanaimo, British Columbia: infaunal habitat and taphonomic implications. Journal of Foraminiferal Research 27, 51-68.

Patterson, R.T., Hutchinson, I., Guilbault, J.P. and Clague, J.J. 2000. A comparison of the vertical zonation of diatom, foraminifera, and macrophyte assemblages in a coastal marsh: implications for greater paleo-sea level resolution. Micropaleontology 46, 229-244.

Pilkey, O.H, Neal, W.J., Riggs, S.R., Webb, C.A., Bush, D.M., Pilkey, D.F., Bullock, J. and Cowan, B.A. 2002: The North Carolina Shore and its Barrier Islands. Duke University Press.

Redfield, A.C. 1972. Development of a New England salt marsh. Ecological Monographs 42, 201-237.

Riggs, S.R. 2001. Shoreline erosion in North Carolina estuaries. The soundfront series UNCSG-01-11, North Carolina Sea Grant.

Saffert, H. and Thomas, E. 1998. Living foraminifera and total populations in salt marsh peat cores: Kelsey Marsh (Clinton, CT) and the Great Marshes (Barnstable, MA). Marine Micropaleontology 33, 175-202.

Schlesinger, W.H. 1997. Biogeochemistry: An analysis of global change. Academic Press.

Schwartz, F.W. and Chestnut, A.F. 1973. Hydrographic Atlas of North Carolina Estuarine and Sound Waters. University of North Carolina Sea Grant Publication UNC-SG-73-12.

Scott, D.B. and Hermelin, J.O.R. 1993. A device for precision splitting of micropaleontological samples in liquid suspension. Journal of Paleontology 67, 151-154.

Scott, D.B. and Medioli, F.S. 1978. Vertical zonation of marsh foraminifera as accurate indicators of former sea levels. Nature 272, 528-531. 
Scott, D.B. and Medioli, F.S. 1980. Quantitative studies of marsh foraminiferal distributions in Nova Scotia: Implications for sea level studies. Cushman Foundation for Foraminiferal Research Special Publication 17, 58p.

Sen Gupta, B. (Ed) 1999: Modern Foraminifera. Kluwer Academic Publishers.

Shennan, I. 2007. Sea level studies. In Elias, S.A. (Ed), Encyclopaedia of Quaternary Science. Elsevier, 2967-2974.

Shennan, I. 1992. Late Quaternary sea-level changes and crustal movements in eastern England and eastern Scotland: an assessment of models of coastal evolution. Quaternary International 15, 161-173.

Shennan, I. 1986. Flandrian sea-level changes in the Fenland II: tendencies of sea-level movement, altitudinal changes and local and regional factors. Journal of Quaternary Science 1, 156-178.

Stephenson, M.H., Leng, M.J., Vane, C.H. Osterloff, P.L., and Arrowsmith, C. 2005. Investigating the record of Permian climate change from argillaceous sediments, Oman. Journal of the Geological Society of London 162, 641-651.

Stephenson, M.H., Millward, D. Leng, M.J. and Vane, C.H. 2008. Palaeoecological and possible evolutionary effects of early Namurian (Serpukhovian, Carboniferous) glacioeustatic cyclicity. Journal of the Geological Society of London 165, 993-1005.

Tanner, B.R., Uhle, M.E., Kelley, J.T. and Mora, C.I. 2007. $C_{3} / C_{4}$ variations is salt-marsh sediments: an application of compound specific isotopic analysis of lipid biomarkers to late Holocene palaeoenvironmental research. Organic Geochemistry 38, 474-484.

Törnqvist, T.E., Bick, S.J., van der Borg, K. and de Jong, A.F.M. 2006. How stable is the Mississippi Delta? Geology 34, 697-700.

Törnqvist, T.E., Wallace, D.J., Storms, J.E.A, Wallinga, J., van Dam, R.L., Blaauw, M., Derksen, M.S., Klerks, C.J., Meijneken, C. and Snijders, E.M.A. 2008. Mississippi delta subsidence primarily caused by compaction of Holocene strata. Nature Geoscience 1, 173-176.

Ungar, I.A. 1991. Ecophysiology of Vascular Halophytes. CRC Press.

van de Plassche, O. (Ed.) 1986. Sea-level research: a Manual for the Collection and Evaluation of Data. Geo Books.

Vane, C.H. 2003. The molecular composition of lignin in spruce decayed by white-rot fungi (Phanerochaete chrysosporium and Trametes versicolor) using pyrolysis-GC-MS and thermochemolysis with tetramethylammonium hydroxide. International Biodegradation and Biodeterioration 51, 67-75.

Vane, C.H., Drage, T.C. and Snape, C.E. 2003. Biodegradation of Oak (Quercus Alba) wood during growth of the shiitake mushroom (Lentinula edodes): A molecular approach. Journal of Agriculture and Food Chemistry 51, 947-956. 
Vane, C.H., Drage, T.C., Snape, C. E., Stephenson, M.H. and Foster, C. 2005. Decay of cultivated apricot wood (Prunus armeniaca) by the ascomycete Hypocrea sulphurea using solid state ${ }^{13} \mathrm{C}$ NMR and off-line thermochemolysis with GC-MS. International Biodegradation and Biodeterioration 55, 175-185.

Vane, C.H. Drage.,T.C. and Snape., C.E. 2006. Bark decay by the white-rot fungus Lentinula edodes: Polysaccharide loss, lignin resistance and the unmasking of suberin. International Biodegradation and Biodeterioration 57, 14-23.

Wang, X-C., Chen, R.F. and Berry, A. 2003. Sources and preservation of organic matter in Plum Island salt-marsh sediments (MA, USA): long-chain n-alakanes and stable carbon isotope compositions. Estuarine and Coastal Shelf Science 58, 917-928.

Walton, W.R. 1952. Techniques for recognition of living foraminifera. Contributions from the Cushman Foundation for Foraminiferal Research 3, 56-60.

Williams, A.B., Posner, G.S., Woods, W.J. and Deubler, E.E. 1973. A Hydrographic Atlas of larger North Carolina Sounds. University of North Carolina sea grant publication. UNC-SG-7302.

Wilson, G.P., Lamb, A.L., Leng, M.J., Gonzalez, S. and Huddart, D. 2005. Variability of organic $\delta^{13} \mathrm{C}$ and $\mathrm{C} / \mathrm{N}$ in the Mersey Estuary, U.K. and its implications for sea-level reconstruction studies. Estuarine, Coastal and Shelf Science 64, 685-698.

Woerner, L.S. and Hackney, C.T. 1997. Distribution of Juncus roemerianus in North Carolina tidal marshes: the importance of physical and biotic factors. Wetlands 17, 284-291. 


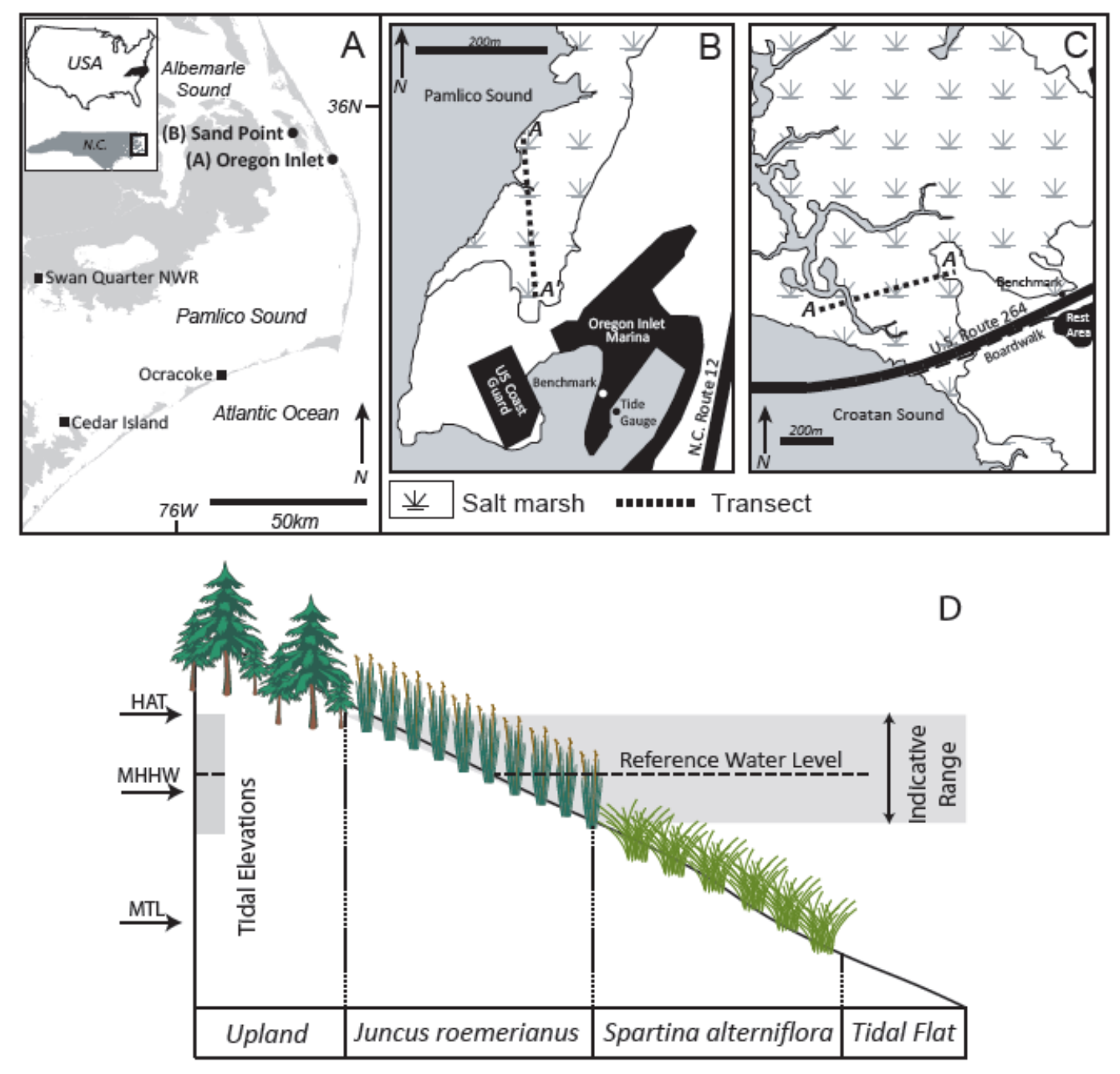




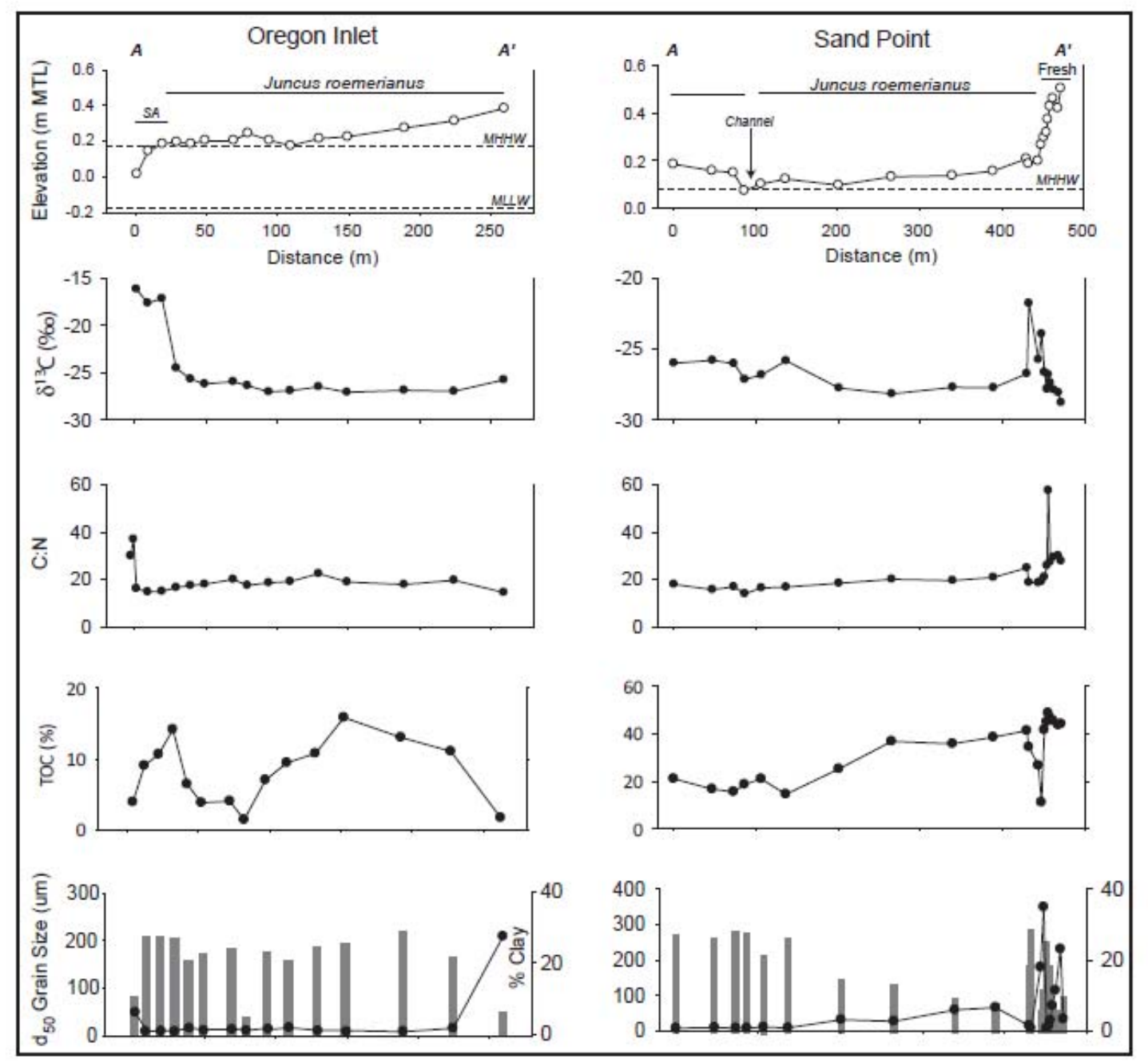




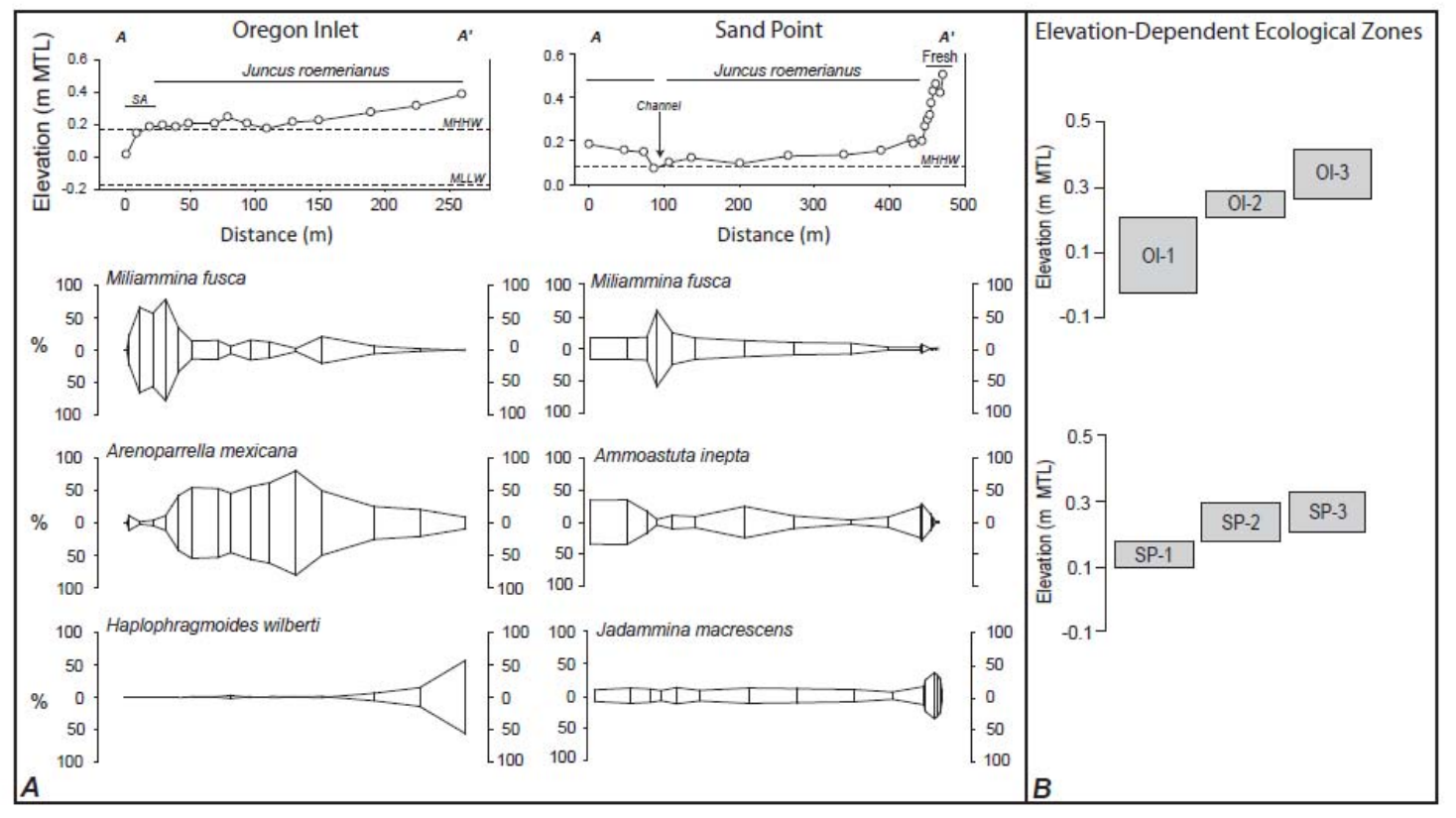




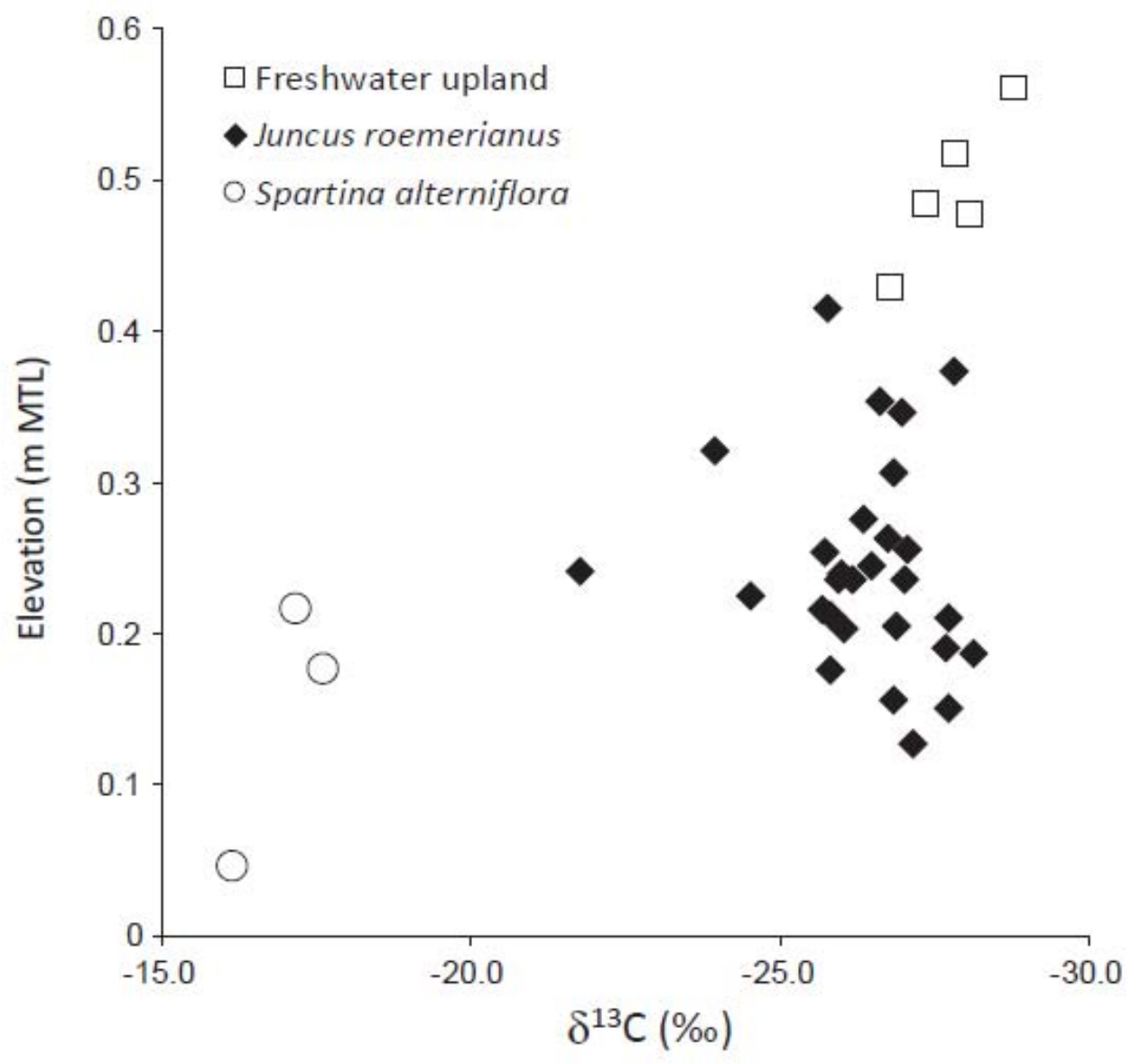




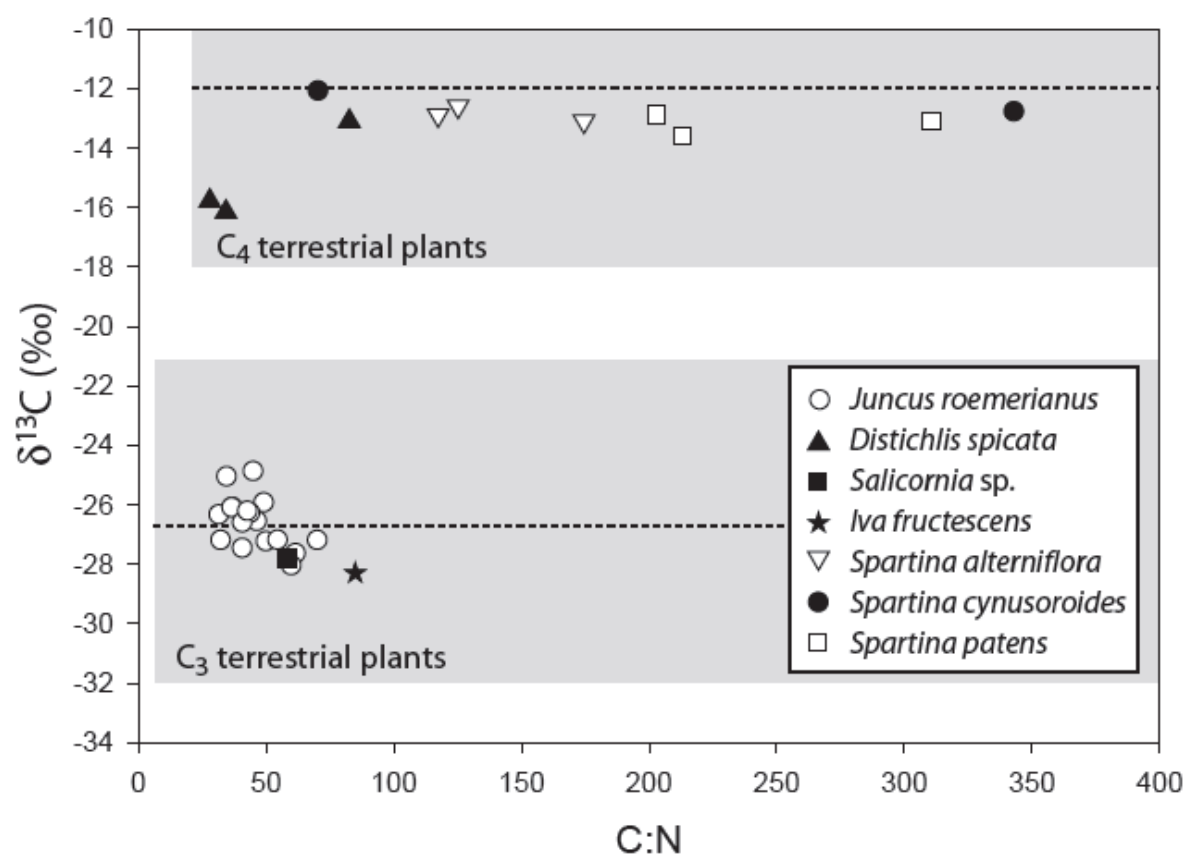



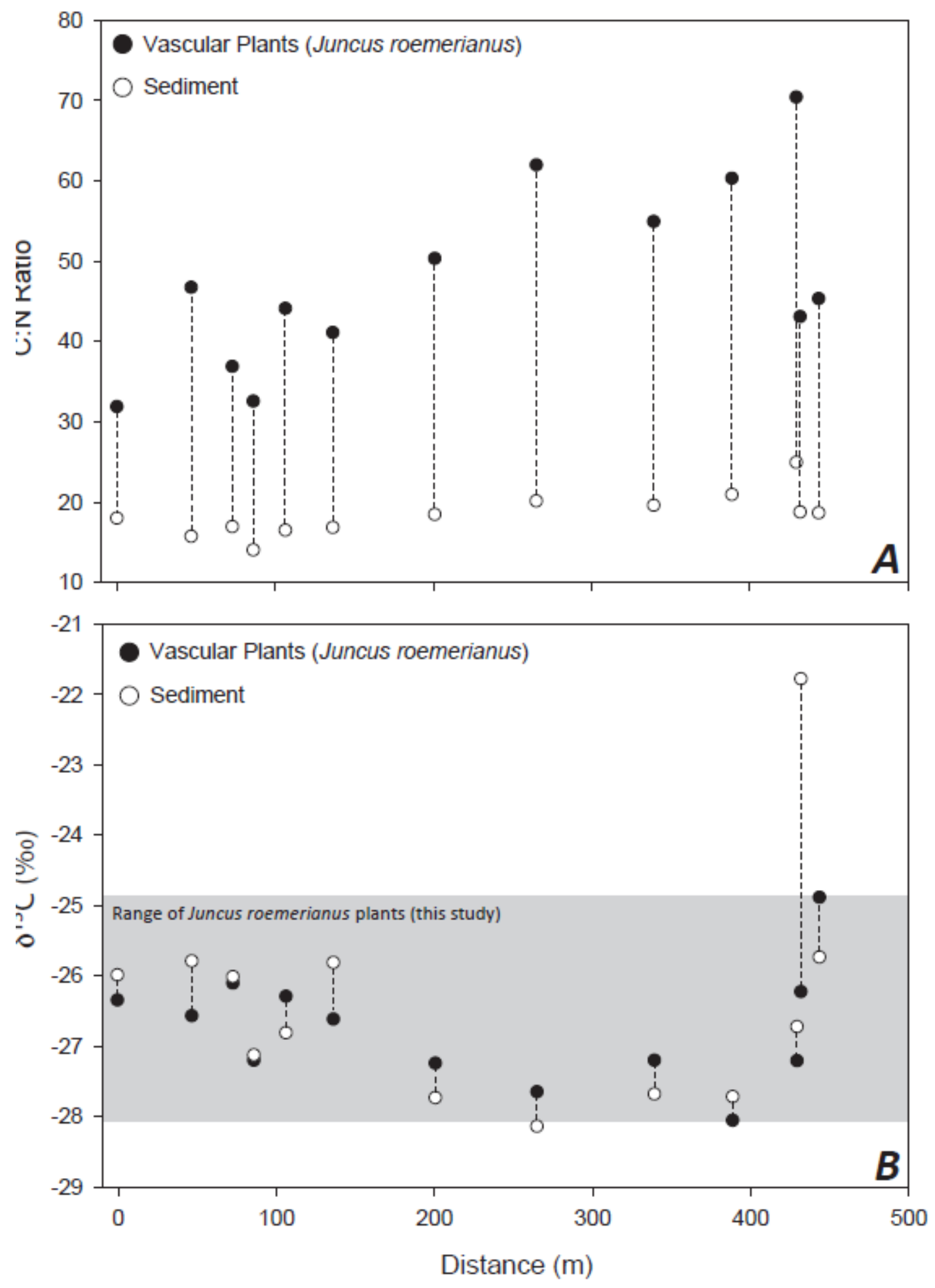


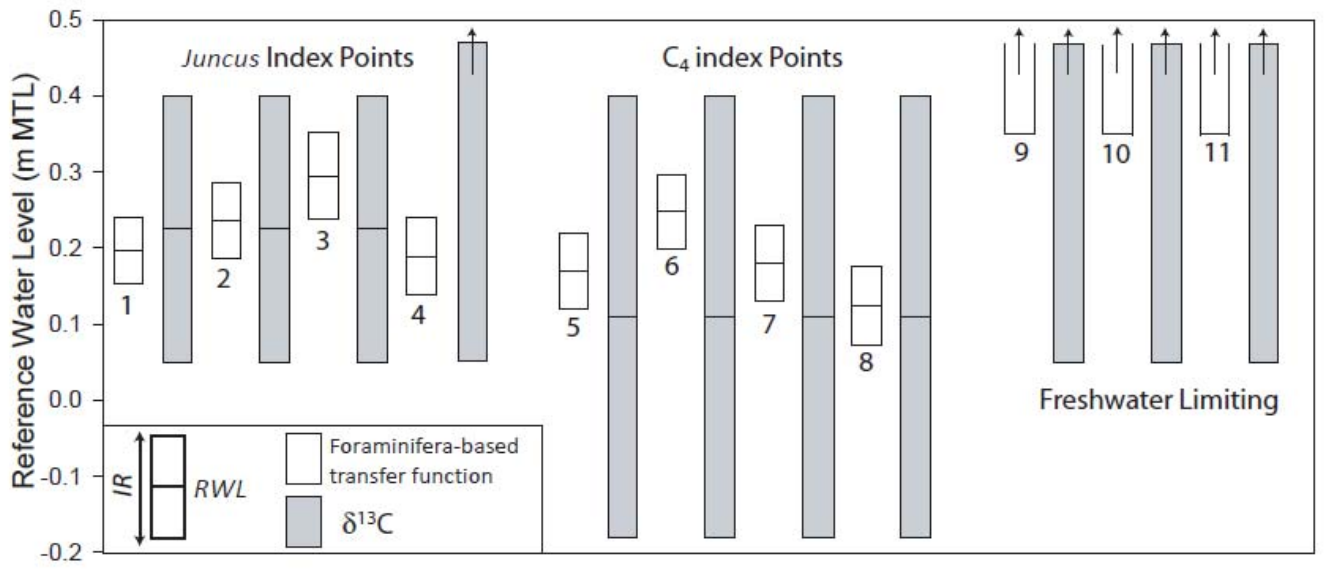

